\title{
BILLS OF RIGHTS IN "THE THIRD WORLD" SOME COMMONWEALTH EXPERIENCES
}

\author{
By James S. READ
}

\section{Introduction}

Enforceable "bills of rights" are now included in the constitutions of the majority of the thirty-two independent member states of the Commonwealth. This discussion indicates their sources and examines briefly their impact to date in the circumstances of "third world" states and especially in the context of the common law. The vogue for detailed and justiciable bills of rights in new Commonwealth states was a remarkable and significant phenomenon during the peak period of British decolonisation in the 1960s. Almost every one of the independence constitutions which took effect during that decade included a chapter giving specific guarantees of the fundamental rights and freedoms of the individual indeed, Tanganyika was the only significant exception. Yet such bills of rights were, in conventional British constitutional theory, generally considered to be not merely unnecessary in the light of the empirical traditions of the common law and the "Westminster model" of government, but alien to these traditions and possibly even dangerous, in as much as they might replace effective legal protection at common law by insubstantial constitutional provisions. However, even during experience of early constitutional upheaval, radical amendment and breakdown, the bills of rights have shown a remarkable bouyancy; they survive today in most of these new states for, apart from those where constitutional government as a whole is now in abeyance and replaced, for example, by military government, e. g. Ghana, Uganda and Nigeria - and in the latter the bill of rights still has a shadowy existence - only one of these states - Malawi - has formally abandoned constitutional guarantees which previously applied.

Of course, bills of rights were by no means new to the Commonwealth as a whole in the 1960s. The most celebrated earlier example is the bill of rights in the Indian Constitution of 1950. In Ireland constitutional protection for certain rights was included in the Free State Constitution of 1922. Yet it is in one of its newest members that the oldest bill of rights in the Commonwealth, and that with the oldest source, is to be found. For when the Kingdom of Tonga in the Pacific shook off its status as a British protected state and regained full independence in 1970, it retained in its Constitution the detailed bill of rights which had been included when that Constitution was first granted by King George Tupou I in 1875. (Apart from the Constitution of Canada of 1867 this is the oldest surviving written constitution in the Commonwealth.) The Tonga provisions represent a unique tradition as the only bill of rights in the world which was originally based on that of nineteenth century Hawaii, long since defunct in Hawaii itself. King George had been in contact with the Hawaiian Consul-General for Australia and the Western Pacific from 1854. The substance of the Declaration of Rights of Hawaii, 7 June 1839, was embodied in the successive Constitutions of Hawaii of 1840, 1852 and 1864, and the Consul-General urged King George to adopt a constitution for Tonga 
to ensure recognition as an international power ${ }^{1}$. The Tonga provisions are succinct but comprehensive, guaranteeing personal freedom (with no suspension of "Habeas Corpus" writs except in time of war or rebellion), one law "for Chiefs and commoners Europeans and Tongans", freedom of worship and the press, freedom of petition, fair trial procedures, impartial government and protection of property. Moreover, these provisions were enforceable although the Chief Justice was given power only to suspend the operation of any legislation which infringed the Constitution. The oldest reported case on an constitutional bill of rights in the Commonwealth is that of 1911 in which Skeen, Chief Justice of Tonga, suspended two Ordinances which, by taking away existing rights, were held to infringe section 20: "It shall not be lawful to enact any retrospective laws ${ }^{2} . "$

Most bills of rights adopted within the past decade or so in the majority of new states of the Commonwealth bear a close family resemblance to each other, reflecting their common ultimate sources in the post-war international enthusiasm for the formal declaration of human rights exemplified by the United Nations Universal Declaration of Human Rights (1948) and, more specifically, by the European Convention on Human Rights (1950) which has indeed served as parent model for the Commonwealth provisions. Professor S. A. de Smith, tracing in 1963 the development of bills of rights in the Commonwealth ${ }^{3}$, emphasised that this phenomenon epitomised a remarkable change in traditional British attitudes. He quoted, for example, the conclusion of the Joint Parliamentary Committee on Indian Constitutional Reform (1934):

"either the declaration of rights is of so abstract a nature that it has no legal effect of any kind, or its legal effect will be to impose an embarrassing restriction on the powers of the legislature and to create a grave risk that a large number of laws may be declared invalid by the courts".

The present discussion, noting the continuing fashion for bills of rights in new Commonwealth constitutions in recent years, enquires broadly as to the impact of such provisions, in the political and economic circumstances of what are, for the most part, "third world" states, with reference to the judicial response exemplified in the albeit limited amount of relevant case-law which has been reported to date.

\section{The adoption of Bills of Rights in the Commonwealth}

When the United Kingdom itself adopted a justiciable bill of rights by its adherence to the European Convention on Human Rights, and particularly with its later acceptance of the right of individual petition to the European Commission of Human Rights, this represented a fundamental departure from the traditions of the mother country of the Commonwealth although one in line with contemporary developments in her off-spring, the former dependencies. Not merely would many English lawyers have agreed with Bentham that "Natural rights is

1 Noel Rutherford, Shirley Baker and the King of Tonga (Melbourne, 1971, Oxford University Press), pp.
1854 (Honolulu, 1947, The University of Hawaii Press), chapter X. For The Act of Constitution of
Tonga see The Law of Tonga, Revised edition (Tonga, 1967, Government Printer), chapter 2.
2 In re an application under clause 85 of the Constitution. . Tongan Law Reports 1908-59, Vol. 1
(Tonga, 1961), p. 9. For further cases on the Declaration of Rights see pp. 33 and 85.
3 S. A. de Smith, The New Commonwealth and its Constitutions (London, 1964, Stevens \& Sons), chapter
5. For a historical survey see: G. O. Ezejiofor, Protection of Human Rights under the law (London 1964). 
simple nonsense: natural and imprescriptible rights, rhetorical nonsense - nonsense upon stilts", but the Convention, setting up standards against which even Acts of Parliament could be measured for validity, might appear to threaten the sovereignty of Parliament which is the fundamental principle of the British constitution ${ }^{5}$. Yet in the lively Parliamentary and other public debates in Britain during 1972 over the issue of the alleged loss of sovereignty involved in entering into the European Communities, little has been heard of the invasion of Parliamentary sovereignty which has already occurred with adhesion to the Human Rights Convention. It is, of course, true that many of the rights protected by constitutional provisions elsewhere are protected in the United Kingdom itself in various other ways - for example, by hallowed devices such as the writ of Habeas Corpus, by well established rules of the common law or by recognised conventions which are accepted as governing political behaviour. Nevertheless, such protection can never be as detailed, comprehensive and over-reaching as that provided by a constitutional bill of rights - and yet, as appears to have occurred in some courts in the Commonwealth, the existence of apparent common law parallels may serve to inhibit the fullest amplification in practice of rights newly defined by constitutional guarantees.

Apart from Tonga and Ireland, India and Pakistan were the first Commonwealth states to adopt bills of rights. The Indian Constitution (1950) includes as well as directive principles of state policy a justiciable bill of fundamental rights; this is pre-eminent in significance in the comparative study of Commonwealth constitutional laws for it has been the basis of a vast amount of litigation resulting in an intricate jurisprudence of human rights ${ }^{6}$. The judicial response to the bill of rights in India, precipitating on occasion acute conflict between the courts on the one hand and the government and Parliament on the other, reached its peak in the famous and controversial Supreme Court decision of 1967 which affirmed that the fundamental rights provisions were themselves, in effect, beyond the reach of any constitutional amendment ${ }^{7}$. This decision in turn has purportedly been superseded by an amending Act of $1971^{8}$ but the validity of this Act is not surprisingly in issue before the courts at the present time. Why has the Indian experience of litigation on human rights questions been so very different from that of most other Commonwealth states, where such cases are as yet generally rare? The answer is no doubt complex, relating to the traditions of the bench and the bar, the extent of education, the degree of politicisation within the nation, the general degree of litigiousness and the extent to which the courts are institutionalised as instruments for the determination of conflict. (Of course, the size of the Indian nation is also relevant, providing as it does more than half of the total population of the Commonwealth.) A bill of rights was included in the Constitution of Malaya at independence in $1957^{\circ}$, but not in that of Ghana which also became independent in 195710. The short-lived Pakistan Constitution of 1956 included a bill of rights.

\footnotetext{
4 “Anarchical fallacies", quoted by de Smith, op. cit., p. 164.

5 See on this point D. R. Gilmour, "The Sovereignty of Parliament and the European Commission of

6 The literature is voluminous. See Alan Gledhill, Fundamental Rights in India (London, 1955, Stevens \& Sons); Alan Gledhill, The Republic of India (London, Second edition, 1964, Stevens \& Sons), chapter 11. 7 Golak Nath v. State of Punjab A. I. R. 1967 S. C. 1643.

8 The Constitution (Twenty-Fourth Amendment), Act 1971.

9 Federation of Malaya Independence Order in Council, S. I. 1957 No. 1533.

10 Ghana (Constitution) Order in Council, S. I. 1957 No. 277; see, however, sections 31 and 34 which prohibited racially discriminatory laws and protected freedom of conscience and religion and certain property rights.
} 
The impetus for the adoption of bills of rights virtually as standard elements in the independence constitutions during the 1960s came with the inclusion of such provisions in the Federal Constitution of Nigeria in 1959 and their retention at Nigerian independence in 196011 . The recommendation for such provisions was made by an official commission which had examined the problems of minority ethnic groups within the federal regions of Nigeria ${ }^{12}$. The Nigerian bill of rights was modelled on the European Convention and has itself served as a principal model for the constitutions of most Commonwealth states which have become independent subsequently. Over the years the precise form in which the rights are stated in different constitutions has been the subject of refinement in drafting and some subtle modifications or expansions of definition have been introduced. For the latest versions of a bill of rights on the Commonwealth model reference may be made to the current constitution of Fiji or Mauritius ${ }^{13}$.

Apart from the independent member states of the Commonwealth, Britain's "associated states" in the Caribbean, which have an anomalous constitutional status with full internal autonomy and the right to opt for independence but with foreign affairs and defence otherwise within United Kingdom control, also have

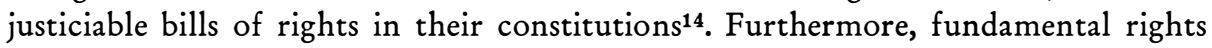
are similarly protected in many of Britain's few remaining dependencies. Not merely did the United Kingdom extend the application of the European Convention to over 40 dependent territories in $1953^{15}$, but now bills of rights upon the common model have been inserted in the constitutional instruments of many dependencies - for example, Gibraltar, the Gilbert and Ellice Islands ${ }^{\mathbf{1 6}}$.

Within the Commonwealth family two separate strands of development in this context must be distinguished from the main pattern which has been outlined. In 1960 the Canadian Parliament passed an Act embodying the Canadian Bill of Rights, a short statement of fundamental rights which, while not enforceable as a constitutional text, established standards in conformity with which all other Acts and subsidiary legislation must be interpreted (unless an Act expressly over-rides the declaration of rights) ${ }^{17}$. The Bill of Rights was invoked in a number of cases, but the Canadian courts were for some years uncertain as to its precise effect: at one time it was held to provide only a standard of interpretation of statutes which did not necessarily invalidate inconsistent provisions in earlier Acts. At this point a government White Paper issued by Pierre Trudeau when he was

11 Nigeria (Constitution) (Amendment No. 3) Order in Council, S. I. 1959 No. 1772; Nigeria (Constitution) Order in Council, S. I. 1960 No. 1652.

12 Cmnd. 505

13 Fiji Independence Order 1970, S. I. 1970 p. 6630; Mauritius Independence Order 1968, S. I. 1968 p. 1871. For other constitutions cited in this article see: Jamaica (Constitution) Order in Council 1962, S. I. 1962 No. 1550; Malta Independence Order 1964, S. I. 1964 No. 1398; Guyana Independence Order 1966, S. I. 1966 No. 575; Botswana Independence Order 1966, S. I. 1966 No. 1171; Swaziland Independence Order 1968, S. I. 1968 No. 1377; Lesotho Independence Order 1966, S. I. 1966 No. 1172; Constitution of Kenya Act 1969, No. 5. For constitutions discussed herein which have subsequently been significantly amended or replaced see: Gambia Independence Order 1965, S. I. 1965 No. 135; Sierra Leone (Constitution) Order in Council 1961, S. I. 1961 No. 741; Zambia Independence Order 1964, S. I. 1964 No. 1652; Uganda (Independence) Order in Council 1962, S. I. 1962 No. 2175; For a comprehensive sourcebook of national and international provisions see: Ian Brownlie (ed.), Basic documents on human rights (Oxford, 1971, Clarendon Press).

14 The six Associated States are: Antigua, Dominica, Grenada, St. Christopher-Nevis-Anguilla, St. Lucia and St. Vincent. For their constitutions see The West Indies Act 1967 chapter 4, and respectively, S. I. 1967 Nos. 225-229, S. I. 1969 No. 1500 (St. Vincent).

15 Cmd. 9045.

16 Gibraltar Constitution Order 1969, S. I. 1969 p. 3604; Gilbert and Ellice Islands Order 1967, S. I. 1967 p. 5860 .

178 \& 9 Eliz. II c. 44. There are also important provisions in this area in provincial legislation in Canada: see, e. g., The Saskatchewan Bill of Rights, R. S. S. 1965 c. 378, which protects a number of fundamental rights; more limited in effect are the Human Rights Code of Ontario, Ont. 1961-62 c. 93, as amended, the Human Rights Act of Alberta, S. A. 1966 c. 39, and the Human Rights Act of Nova Scotia, S. N. S. 1963 c. 5, which deal basically with discrimination. 
Minister of Justice proposed the entrenchment of a Bill of Rights in the Canadian Constitution. This precipitated an interesting illumination of the essential issue involved:

"What is the best constitutional blending of parliamentary supremacy and judicial supremacy in defining the issues in determining the means by which human rights and freedoms are to be protected?"

Ironically, the politician's proposal of judicial supremacy was rejected by a judge who, making an official report at provincial level, recommended the retention of parliamentary supremacy: McRuer, C. J., proposing the adoption of a bill of rights for Ontario, considered that, without entrenchment, it might be wider in scope and more useful and that in any case Parliament should normally have the power to over-rule the courts ${ }^{18}$. In the event the Canadian Supreme Court held in 1969 that the Bill of Rights had the effect of invalidating earlier legislation inconsistent with it, accepting that the Bill established over-riding general principles and not mere rules of interpretation ${ }^{19}$. The Canadian version was, however, given constitutional entrenchment elsewhere for it was the model for the short bill of rights in the independence constitution of Trinidad and Tobago ${ }^{20}$ : the definition of rights protected is terse; an Act may derogate from the rights if it is passed by a three-fifths majority of all members in each of the two Parliamentary chambers. The Canadian model was also invoked when a Bill of Rights was proposed in the New Zealand Parliament in 1963; it was not, however, enacted.

A second type of development is the inclusion in the new Constitution which brought to birth the Republic of Sri Lanka on 22 May 1972 of a short section on "Fundamental Rights and Freedoms" 21. (It has already been noted that the former Constitution of Ceylon did not include a bill of rights.) The new provision states certain basic rights somewhat briefly but qualifies them significantly by permitting "such restrictions as the law prescribes in the interests of national unity and integrity, national security, national economy, public safety, public order, the protection of public health or morals or the protection of the rights and freedoms of others or giving effect to the Principles of State Policy". And quite apart from these qualifications, the Constitution also stipulates that no court may inquire into or pronounce upon the validity of any law made by the National Assembly, thus preventing any judicial remedy in the event of a new law appearing to derogate from the rights declared; the instrument provided for the interpretation and application of all constitutional provisions being the Constitutional Court which has jurisdiction to examine bills only, with power to give a final decision as to their constitutionality only in advance of enactment and provided that the Court has been moved within a week of the bill being placed on the Parliamentary agenda.

The constitutional protection of human rights has had a particularly uneven history in Southern Rhodesia. The Constitution of $1961^{22}$ followed the vogue and included justiciable guarantees of individual freedom. As a result of the

18 Royal Commission: Inquiry into Civil Rights, Vol. 4 (Queen's Printer, Ontario, 1969), p. 1568; the quotation is from p. 1497. The Federal White Paper, A Canadian Charter of Human Rights, was published in February 1968.

19 R. v. Drybones (1969) 9 D. L. R. (3rd) 473, [1970] S. C. R. 282, described as "the most important case yet in the history of the development of civil liberties in Canada" by J. C. Smith: "Regina v. Drybones and Equality before the Law", Canadian Bar Review, Vol. XLIX (1971), pp. $163-87$.

20 Trinidad and Tobago (Constitution) Order in Council 1962, S. I. 1962 No. 1875, ss. 1-8.

21 S. 18.

22 Southern Rhodesia (Constitution) Order in Council 1961, S. I. 1961 No. 2314. 
political developments involving the Illegal Declaration of Independence in 1965 the protective provisions were removed from the body of the Constitution and relegated (in the 1969 Constitution) to the appendix where they now appear, no longer being justiciable. In the proposals for a settlement of the Rhodesian problem agreed in 1971 between the Rhodesian and United Kingdom Governments ${ }^{23}$, an important element, from the British point of view, was claimed to be the agreement to restore the bill of rights as a justiciable part of the Constitution. However, the bill as then proposed would in several respects be inferior to those in most other Commonwealth states - for example, permitting exceptions to the rule against racial discrimination on an unusually wide basis and also expressly preserving all existing laws, a number of which embody discriminatory or oppressive provisions.

The common feature of the bills of rights discussed herein is their justiciability. Ringing declarations of human rights are, of course, found in many constitutions throughout the world; they are often more impressive in terms of literary style than in practical enforceability. The Republican Constitution of Ghana (1960) included a high sounding "Declaration of Fundamental Principles" to which the President, upon assuming office, avowed his adherence. This Declaration included guarantees against discrimination, for the preservation of the chieftaincy and for freedom of religion, speech, movement, assembly and access to the courts; there was also a declaration that every Ghanaian "should receive his fair share of the produce yielded by the development of the country". An attempt was indeed made to argue that the declaration provided a justiciable bill of rights limiting the legislative power, but the Supreme Court rejected this argument, declining to hold invalid the Preventive Detention Act ${ }^{24}$.

The independence Constitution of Malawi25 included a full bill of rights, but this was abandoned when the republican Constitution of 1966 was adopted ${ }^{26}$; instead there is one section which states certain "Fundamental principles of government", including:

"(iii) The Government and the people of Malawi shall continue to recognize the sanctity of the personal liberties enshrined in the United Nations Universal Declaration of Human Rights, and of adherence to the Law of Nations:

(iv) No person should be deprived of his property without payment of fair compensation, and only where the public interest so requires;

(v) All persons regardless of colour, race or creed should enjoy equal rights and freedoms; ..."

These broadly framed provisions lack precision and would therefore not appear to be susceptible to judicial enforcement; but the immediately following subsection provides that "Nothing contained in or done under the authority of any law shall be held to be inconsistent with or in contravention of subsection (1) to the extent that the law in question is reasonably required in the interests of defence, public safety or public order". Such a qualification implies that the principles themselves might be justiciable (although the exceptions permitted are, of course, very widely defined - as is true in many other states).

23 Cmnd. 4835

24 Re Akoto, Civil Appeal No. 42 of 1961

25 Malawi Independence Order 1964, S. I. 1964 No. 916.

26 Act No. 23 of 1966. 


\section{Human rights in the third world}

Was the adoption of bills of rights, framed upon the pattern of the European Convention, a wise policy in new states of the "third world", whose immediate political, social and economic problems are commonly regarded as being more urgent than, and different in kind from, those of European states. Is it justifiable to give such emphasis to the protection of individual rights by provisions which inevitably owe much of their philosophical background to the Judeo-Greco-Roman-Christian traditions which underly modern notions of constitutionalism in the west? These new states of the Commonwealth, in Asia, Africa, the Caribbean or the Pacific, are characterised by severe, often desperate, problems of poverty, illiteracy and disease, with very restricted economic possibilities, rising population figures and the pressures of rapid social change and of the revolution in expectations. Many have additional problems of ethnic division and communal mistrust, creating daunting tasks of nation-building within inherited colonial boundaries. Such factors can, of course, be argued to make the protection of individual rights the more important: the temptations and opportunities for authoritarianism in government and bureaucracy being considerable. And while most of the written constitutions in which these bills of rights appear are based upon "the Westminster model" of government to a large degree; nevertheless in practice with poorly founded party systems, slender and hard pressed bureaucratic machinery, a lack of effective balancing institutions and the survival of locally traditional political institutions, loyalties and methods, these political systems are of ten unstable. Modern government apparatus may be insufficiently accepted locally - for example, the superior courts and the legal profession may be remote from the majority of people (although in some Commonwealth states modern judicial procedures have been institutionalised to a remarkable degree for the purpose of settling even political disputes, as in Nigeria).

Thus it may be argued that constitutions, drafted mainly by lawyers at the Colonial Office in London upon principles agreed between local leaders and representatives of the United Kingdom government, accord only partially with real local needs, representing a compromise solution provisionally accepted in order to expedite independence. Individual rights are protected: but in present circumstances leaders of these new states may be more concerned to impress upon their people the obligations owed by individuals to their societies. Bills of rights protect mainly political and related freedoms - some African leaders at least considered that guarantees of work, food, education and health would be as welcome ${ }^{27}$; ironically such economic rights are represented in these bills only by the protection afforded to existing property rights, which arguably inhibit the drastic changes in economic structure which may be desirable in some states. Lawyers can more readily assure negative rights - of non-interference by others with individual freedom - than positive ones requiring economic resources for their fulfilment; but the negative role alone is an inadequate one and may be a cause of imbalance.

\footnotetext{
27 See, for example, the experience of a lawyer who advised the leaders of Basutoland: D. V. Cowen, "Human rights in contemporary Africa", Natural Law Forum, Vol. 9, No. 1 (1964). For a major and seminal work on this subject by the same author see D. V. Cowen, The Foundations of Freedom with special reference to Southern Africa (Cape Town, 1961).
} 
Yet, although many of the new states of the Commonwealth have, in their short lifetimes, experienced considerable political change involving constitutional amendments of substantial character, in only one case has the bill of rights disappeared from the current constitution (Malawi). Even under military government the fundamental rights provisions of the constitution may be excluded from the suspension of parts of the constitution, as in Nigeria (although such provisions can no longer prevail over inconsistent laws ${ }^{28}$ ). And a most instructive case in this respect is that of Ghana. The short-lived Constitution of 1969, under which civilian democratic rule was restored after the period of military government, and which cannot be regarded as a foreign imposition, went further than any other in the Commonwealth in its endeavour to prescribe in detail the fundamental rights of the individual and to entrench these rights beyond the reach of any constitutional amendment which might derogate from them. The stimulus for that indulgence in attempted legal "overkill", with its "failsafe" entrenchment provisions and double-locked guarantees, is no doubt to be found in Ghana's experience 'of authoritarian rule before the military coup of 1966, under the Convention People's Party. It has been seen that the independence Constitution of Ghana had not included a bill of rights; but it is instructive to recall that this omission was apparently at the will of the British Government. The then Attorney General of Ghana has recounted how the then Gold Coast Government prepared a draft of the constitution which it wished to adopt for the independence of the country; the draft included seven articles for the protection of fundamental rights, mainly based upon provisions in the Constitutions of India and of the Irish Free State. The draft proposed was rejected as a whole by the United Kingdom Government and Ghana at independence had no bill of rights ${ }^{29}$.

Despite the evidence of support for constitutional guarantees among the leaders of new states in the Commonwealth, there are several respects in which bills of rights may be said to be out of accord with the third world context in which they operate. Thus, Asian and African religions, cultures and social systems do not necessarily share the same values which have inspired the definition of human rights in western nations. The community, and the duties imposed by custom, religious law and family ties may rank higher than some aspects of individual freedom, although of course in this respect many changes are taking place. An Indian jurist has endeavoured to show that the Indian bill of rights accords not only with western values but also with the duty-oriented concepts of Hindu jurisprudence, resting his argument upon the "indirect duties" which flow from the restrictions imposed upon guaranteed rights, and upon the "direct duties" imposed by a very few provisions which stipulate individual obligations (such as the prohibition of race discrimination and of the practice of "untouchability"). ${ }^{\mathbf{3 0}}$ He emphasises also that, in contrast to western and particularly American constitutional practice, Indian courts have accepted that the Constitution imposes obligations upon individuals towards other individuals (as well as upon governments). He concludes that "the Constitution has given as much importance to the duty of the individual as to his rights" - a some what bold finding except

28 Constitution (Suspension and Modification) Decree 1966, Decree No. 1 (Nigeria). See D. O. Aihe, "Fundamental human rights and the military regime in Nigeria: What did the courts say?" [1971] J. A. L. $213-24$.

29 Geoffrey Bing, Reap the Whirlwind (London, 1968, Macgibbon \& Kee), Appendix.

$30 \mathrm{~K}$. P. Krishna Shetty, Fundamental Rights and Socio-Economic Justice in the Indian Constitution (Allahabad, 1969, Chaitanya Publishing House), chapter 3. 
on the universal basis that one man's right implies the duty of non-interference for others. (It is interesting to note here that whereas some other Commonwealth constitutions refer in the main only to the conduct of governments and public officers, others, like the Indian bill of rights, expressly offer protection also against certain private actions too, particularly in the area of racial and other discrimination in places of public resort. Thus discriminatory treatment in respect of access to shops, hotels, restaurants and places of public entertainment is forbidden by the constitutions of $\mathrm{Fiji}^{31}$, Kenya ${ }^{32}$, Swaziland ${ }^{33}$ and Lesotho ${ }^{34}$ ).

Then, the recent history of these new nations was scarcely an appropriate preparation for the maximum enjoyment of individual rights and freedoms. Colonial rule was essentially authoritarian and even the introduction of English law as the bassis for the local legal system did not result in the colonial subjects enjoying the full rights of liberty, due process, free speech and the rest which the common law is said to guarantee to the Englishman himself. The convenient although ill-defined doctrine of "indirect rule", buttressing the powers of traditional rulers, the creation of special "native courts" to administer unwritten "customary laws" and administrative orders, the exercise of powers of political detention or deportation and the use of laws of sedition and consorhip framed more widely than in England - these were significant intrusions upon the rule of law which preserves English liberties ${ }^{35}$.

Furthermore, as already noted, individual freedoms may appear somewhat luxurious in the socio-economic context of third world states. Moreover the fragility of political orders in many new states erodes the foundations upon which bills of rights appear to rest. Of the twelve Commonwealth states in Africa five have experienced coups and three are at present ruled by military governments; two others have adopted de iure single-party systems and a third is now doing so. Elaborate constitutional models, incorporating guarantees of individual rights, but destined for early collapse may be less effective in securing liberty than more realistic and stable political structures which lack such specific provisions.

Here the Tanzanian example is an instructive one. Neither at independence or since has the Constitution included a bill of rights. The Presidential Commission which prepared the framework of the present Interim Constitution ${ }^{36}$ of the oneparty state recommended against the adoption of a bill of rights; its reasoned conclusion was "that the rights of the individual in any society depend more on the ethical sense of the people than on formal guarantees in the law"37. The Commission noted that British freedoms rest upon the consensus between people and leaders, not upon the law (which a Parliamentary majority can change). Three reasons were given to support this considered rejection of a bill of rights. "A Bill of Rights limits in advance of events the measures which Government may take to protect the nation from the threat of subversion and disorder. However, the course of events cannot always be foreseen and constitutional guarantees for the individual will defeat their own purpose if they serve to protect those whose

\footnotetext{
31 See the Constitution cited in footnote 13 above, section 15 (6).

32 See the Constitution cited in footnote 13 above, section 82 (7).

33 See the Constitution cited in footnote 13 above, section 15 (8)

34 See the Constitution cited in footnote 13 above, section 17 (7)

35 This point is emphasised by Y. P. Ghai and J. P. W. B. McAuslan, Public Law and Political Change in Kenya (Nairobi, 1970, Oxford University Press), passim. For another view see H. F. Morris and James S. Read, Indirect Rule and the Search for Justice (Oxford, 1972, Clarendon Press).

36 Report of the Presidential Commission on the Establishment of a Democratic one Party State (Dar es Salaam, 1965, Government Printer), pp. 30-33.

37 Ibid., p. 32.
} 
object is to subvert and destroy democracy itself." "... a Bill of Rights would invite conflict between the Judiciary and the Executive and Legislature . . . the Judiciary would be drawn into the arena of political controversy." "Tanganyika has dynamic plans for economic development. These cannot be implemented without revolutionary changes in the social structure ... Decisions concerning the extent to which individual rights must give way to the wider considerations of social progress are not properly judicial decisions. They are political decisions best taken by political leaders responsible to the electorate."

As an alternative mode for protecting the rights of the individual, the Commission proposed the establishment of a type of Ombudsman, in the form of the Permanent Commission of Inquiry, a body which has now been active for several years in Tanzania with a wide jurisdiction to investigate complaints from individuals of the abuse of power by government or party officials or other public officers. The Permanent Commission is widely considered to have been remarkably successful in gaining the confidence of the people and in investigating actual cases of maladministration ${ }^{38}$. In some respects more effective than a bill of rights - for its informal and inexpensive procedures are clearly far more accessible to the people, especially in rural circumstances, than court remedies would be - the Commission cannot, of course, offer any remedy for unjust or oppressive laws, as a bill of rights may do. Several Commonwealth states have adopted the Ombudsman (e. g. Fiji, Mauritius, Guyana and New Zealand) ${ }^{39}$.

In rejecting the proposal for a bill of rights the Tanzanian inquiry gave emphasis to the possibility of conflict between government and judiciary, drawing attention to a fact true also of other Commonwealth states even today - that the judiciary included a large expatriate (often formerly colonial service) element. Are the judicial systems, with their apparent remoteness from the ordinary citizen, able to bear the burden of administering constitutional provisions which may bring conflict between the courts and the political leaders?

\section{The contents of bills of rights in the Commonwealth}

Following the general pattern of Articles 2-11 of the European Convention, bills of rights in new Commonwealth states guarantee protection of the rights to life, liberty, due process of law and privacy and freedom of conscience, expression, assembly and association. These constitutional provisions are much more extensive and detailed than the terms of the Convention itself, and include precise definitions of the exceptions or modifications which are allowed to qualify the rights and freedoms. The right to marry and found a family (Article 12 of the Convention) is absent from the constitutions. although the Ghana Constitution of 1969 included as its first substantive article on fundamental rights a provision requiring Parliament to enact laws to protect the family as a whole.

The bill of rights is given prominence as one of the earliest parts of each constitution (although it has been relegated to a later part of the current Kenya Consti-

38 For its powers etc., see the Interim Constitution of Tanzania, 1965, Act No. 43, Part VI and the Permanent Commission of Inquiry Act, 1966, Act No. 25. For its activities see the Annual Reports published by the Government Printer, Dar es Salaam.

39 For Fiji, Mauritius and Guyana see the Constitutions cited in footnote 13 above at chapters IX, IX and V (2) respectively; for New Zealand see the Parliamentary Commissioner (Ombudsman) Act 1962, No. 10. 
tution) and is prefaced by a declaratory preamble. The actual stipulations do not in fact quite accord with this declaration which, for example, affirms that "every person ... is entitled to the fundamental rights and freedoms of the individual . . . whatever his race, place of origin, political opinions, colour, creed or sex ..." Only one of these constitutions, however, actually outlaws sexual discrimination in its operative provisions - the Ghana Constitution of 1969, which also paternalistically required Parliament to pass special laws to give women and children the special care and assistance they were there stated to need.

In contrast to the somewhat terse provision protecting the "peaceful enjoyment of ... possessions" in Article 1 of the First Protocol to the European Convention, protection from deprivation of property in many Commonwealth states is afforded by a lengthy and complex provision increasingly refined by the draftsmen in successive constitutions. In one of the most recent examples, the Constitution of Fiji, the relevant provisions runs to eight sub-sections totalling some 1300 words ${ }^{40}$ : it prohibits compulsory deprivation of possession of, or interests in, any kind of property except in accordance with a law which requires reasonable notice, a Supreme Court order (based upon stated grounds including public safety, order or benefit) and "the prompt payment of adequate compensation" to be determined judicially in the absence of agreement. There is also a guarantee that the compensation paid may be remitted, without deduction or tax, to any country outside Fiji (similar provisions are found in, for example, Kenya, Mauritius, Swaziland and Botswana $)^{41}$. The requirement of prompt and adequate compensation has come to be commonly adopted in Commonwealth states although alternative formulas include "the prompt payment of full compensation" (Kenya, Swaziland and Lesotho) ${ }^{42}$. In Zambia an amendment of $1969^{43}$ introduced a simpler form requiring any compulsory acquisition of property to be authorised by legislation "which provides for payment of compensation".

The rights and freedoms guaranteed are subject to modifications and exceptions defined in several ways. Firstly, each specific article defining a right enumerates also exceptions to it, some of which are inescapable such as loss of liberty consequent upon a criminal sentence. Some exceptions refer to unusual local circumstances - such as the power to acquire "property of the Amerindians of Guyana for the purpose of its care, protection and management" 44 or to restrict the movement of persons who are not Bushmen in parts of Botswana "for the protection or well being of Bushmen"45. Some of the permitted exceptions, however, make such inroads upon the right asserted as in effect to deny it; even the most basic right of all, that of personal liberty, being often highly qualified. In Mauritius the right to personal liberty is qualified by the power of the Commissioner of Police (expressly subject to direction or control from no other person or authority) to order the detention of any person "upon reasonable suspicion of his having engaged in, or being about to engage in, activities likely to cause a serious threat to public safety or public order" 46 . In many states personal freedom is subject to an apparently sweeping exception permitting deprivation of liberty in execution of lawful orders restricting a person to, or excluding him from, any

\footnotetext{
40 Section 8.

41 See the Constitutions cited above in footnote 13 at ss. 75 (4), 8 (2), 8 (3) and 8 (2) respectively.

42 Sections 75 (1), 8 (1) and 16 (1) respectively.

43 Constitution (Amendment) (No. 5) Act 1969, No. 33

44 Constitution of Guyana, cited in footnote 13 above, s. 8 (2) (b) (i).

45 Constitution of Botswana, cited in footnote 13 above, s. 14 (3) (c).

46 Constitution of Mauritius, cited in footnote 13 above, s. 5 (1) (k).
} 
specified area (which area may be of vast or small dimensions); this may well reflect the pattern of colonial "deportation laws" used to "rusticate" troublesome individuals. This exception must however, be read in conjunction with another fundamental right, that of freedom of movement, which is given its own list of exceptions, differently formulated. The overlapping of these two separate rights may be a source of difficulty, as the courts found in Uganda where a detention order under the old Deportation Ordinance, in connection with an order of "restriction", was upheld by the High Court (as being within a defined exception to the right of liberty) but held invalid by the Court of Appeal (as not being within the exceptions listed to the right to freedom of movement) ${ }^{47}$. Where a person is confined, both of these rights are infringed and the government may therefore take advantage of the two sets of exceptions to justify the confinement, in the alternative. (In the Uganda case mentioned yet a third category of exception was invoked after the decision, to continue the detention under emergency provisions.) The Constitution of Guyana ${ }^{48}$ and the former Constitution of Uganda $(1967)^{49}$ frankly recognised as exceptions to the right of liberty the power to make orders of preventive detention - in each case subject to a subsequent early enquiry and recommendation by a tribunal although in Uganda the recommendation was not binding upon government. A striking omission from the constitutions is the absence of any provision comparable to that in the Conven$\operatorname{tion}^{50}$ guaranteeing "an enforceable right to compensation" for every victim of improper detention or arrest.

Secondly, many of the rights stated in the constitutions are subject to qualifications permitting legislation in certain defined public interests (e. g. defence, public safety, order, morality or health) or to protect the rights and freedoms of others. Here the intrusions are themselves subject to a qualifying limitation - they are generally ineffective to over-ride constitutional rights if "shown not to be reasonably justifiable in a democratic society".

Thirdly, some constitutions expressly validate laws existing at the date of the constitution even if they conflict with the fundamental rights. In Jamaica and Guyana $^{51}$ all laws which were in existence when the Constitutions came into force are expressly preserved despite any possible inconsistency with fundamental rights - and the protection extends also to any re-enactment of an "existing law" even with alterations, provided that the law is not then more inconsistent with fundamental rights than it was formerly. In Botswana laws in force at independence are valid even if they infringe on the freedom from discrimination, but the provision does not extend regarding inconsistency with other rights ${ }^{52}$; Fiji has a similar provision relating to laws existing not at independence (1970) but at the date of an earlier constitution (1966) ${ }^{53}$. In most states the protection against inhuman or degrading punishment expressly permits the infliction of any description of penalty which was lawful under "existing laws".

Fourthly, all these constitutions make provision for derogation, within specified limits, from certain fundamental rights protection in emergency situations. Detailed requirements for the procedure for declaring an emergency usually require

47 Ibingira v. Uganda [1966] E. A. 306.

48 S. $5(1)(\mathrm{k})$.

49 S. $10(1)(j)$

50 Article 5.5 .

51 See the respective Constitutions: Jamaica, s. $26(8)$ and (9); Guyana, s. 18

52 Constitution, s. 15 (9).

53 Constitution, s. 15 (5). 
Parliamentary authorisation within a specified period of the formal proclamation. During such an emergency, many of the constitutions provide for other safeguards to come into effect - for example, requiring publicity for detentions and hearings by an impartial advisory tribunal at intervals during any such detention.

In contrast to the machinery established by the European Convention, in none of the Commonwealth states was special machinery established to enforce the fundamental rights declared by the constitutions. In every case enforcement was entrusted to the ordinary superior courts which can hear applications for redress from any person who alleges an actual or anticipated infringement "in relation to him". The constitutions provide that rules of court may be made to govern practice and procedure in such cases; although in many states no such rules have been made the individual is not therefore to be frustrated in his search for a remedy and the court will use whatever procedure may seem most appropriate ${ }^{54}$. In many cases the old English law procedures of the prerogative writs or orders will be used, particularly, of course, in questions concerning personal liberty, the writ of habeas corpus. The courts are empowered to make such orders as they think appropriate to enforce the bill of rights, but they should not do so if alternative and adequate means of redress are available under any other law. Nigerian courts have refused to consider petitions in vacuo: the petitioner must show that a personal right of his own is involved in the case, in accord with the common law tradition that courts do not entertain hypothetical questions $s^{55}$. (In Commonwealth states the judicial structure in the past included at its apex the Judicial Committee of the Privy Council which sits in London; most new states have now terminated this jurisdiction.)

In Zambia an interesting provision enables the Chief Justice, on the request of at least seven members of the National Assembly, to appoint a tribunal of two judges to report whether a bill or subsidiary legislative instrument is inconsistent with the bill of rights. Presidential assent may not be given to a bill before the tribunal reports, but is not expressly precluded by an unfavourable report ${ }^{56}$.

\section{The judicial response}

There are relatively few reported cases from Commonwealth states (apart from India) upon fundamental rights. Lawyers have evidently shown characteristic caution in invoking the bill of rights in court. In those states where conflict has arisen between the judiciary and the government, it has not been precipitated by the application of the constitutional guarantees. Of course the superior courts and even the legal profession are somewhat remote culturally and physically from the mass of the population, and relatively inaccessible to a majority of citizens. Most persons appearing before the lower courts are not legally represented and neither they nor the magistrates, who generally have only limited legal training, are likely to raise constitutional issues in minor cases. It is reported that in Lesotho, during the first three and a quarter years of independence before the Constitution was suspended in 1970, the High Court was not once called upon to determine

\footnotetext{
54 For an analogy see Fajinmi v. The Speaker, Western House of Assembly [1962] 1 All N. L. R. 205.

55 Olawoyin v. Attorney-General, Northern Region [1961] 1 All N. L. R. 269.

56 Constitution, cited in footnote 13 above, s. 27. However, at the time of writing the replacement of this 1964 Constitution is foreshadowed by proposals to adopt a single party system in 1973.
} 
a case involving the human rights provisions ${ }^{57}$. Lower courts themselves might be found to be infringing the bill of rights, as where a customary court in Nigeria continued to convict and sentence persons for the customary law offence of adultery, although the Constitution stipulated that no-one should be punished for an offence unless it were defined by written law ${ }^{58}$. (This important provision involved the demise of unwritten customary criminal law in most Commonwealth states in Africa.)

Other factors in African and Asian societies may contribute to the extra-judicial resolution of conflicts which might otherwise involve fundamental rights. The manipulation of kinship or other links in face to face encounters with bureaucrats or politicians may still be expected to yield more effective results than formal confrontations through the judicial apparatus. The far-reaching influence of a dominant party controlling government with its assorted powers of patronage and coercion is also likely to discourage any but the most determined, or the most offended, from openly attacking state policy or official decisions. But this is not to suggest that the judges themselves may not be alert, when opportunity presents itself, to assert the importance of constitutional guarantees. When, on an appeal against conviction for murder, it appeared that the appellant and witnesses had been detained at the police station for ten days before the appellant's "arrest", the Court of Appeal for Eastern Africa observed: "This procedure appears to show a complete disregard of citizen's right to his personal liberty. This right had always existed in Uganda but now it is entrenched in the Constitution." 59

\section{(i) "Due process" requirements}

The area of fundamental rights which appears to have prompted most litigation is that which may conveniently be termed the "due process" sector. Altbough colonial rule involved many restrictions upon individual rights as they were recognised in the law of England itself, some elements of the bills of rights restate principles familiar in the common law. The Constitution Commission currently studying constitutional reform in Trinidad and Tobago makes the point in its explanatory booklet: after indicating the rights and freedoms now protected under the Constitution, it comments that "the English common law, which is and has been for some considerable time a part of the law of Trinidad and Tobago, had developed a body of rules and procedures designed to protect and therefore to recognise and keep in existence all those rights and freedoms"60. This attitude may, however, lead to a somewhat restrictive judicial approach to the interpretation of the bill of rights, with the underling assumption that the constitution merely restates doctrines which the common law had in any case adequately developed.

It is true that the "due process" provisions prescribing the elements of fair trial procedures to which any accused person is entitled closely correspond to the basic rules of English criminal justice. The constitutional right to legal representation was a convenient ground of appeal where an accused in Nigeria was

\footnotetext{
57 Michael H. Stein and Eileen M. Stein, "Legal aspects of the Lesotho Constitutional Crisis", East African Law Journal, Vol. VI, No. 3 (1970), pp. 210-221 at p. 216.

58 Aoko v. Fagbemi [1961] 1 All N. L. R. 400

59 Ochieng v. Uganda [1969] E. A. 1, 3.

60 Thinking things through (Trinidad, 1972, Government Printery), p. 5.
} 
through no fault of his own deprived of the assistance of his lawyer at his trial, but the courts determined the appeal in favour of the appellant entirely by reference to leading precedents from English and colonial law in the past, before the era of bills of rights ${ }^{61}$. In another Nigerian case on the same point these older cases appear to have been applied to limit the operation of the constitutional guarantee: that appeal was dismissed because the lawyer's absence from the trial was due to the lawyer's own default - hardly an adequate basis upon which to deny the appellant's constitutional right ${ }^{62}$. East African courts have also relied on English precedents in this context, accepting that there is no derogation from the bill of rights if the accused is deprived of legal representation through his own fault or that of his counsel63. Where an accused was defended by counsel assigned by the court, and did not mention that he had instructed his own lawyer, his appeal on the ground that he had lost his constitutional right to a representative "of his own choice" failed64. An English precedent was relied upon where an appellant in Nigeria alleged in vain that he was not given adequate time or facilities to prepare his defence (as the constitution requires) and that his counsel had been absent for part of the proceedings ${ }^{65}$. In another case upon the former point it was emphasised on appeal that adjournments are in the discretion of the trial court, and that "there is no provision in the Constitution which controls or fetters the discretion of the Courts . .."66 It has also been accepted that the right to counsel is not infringed where counsel chosen comes from overseas and, although a member of the local Bar, does not receive permission to enter from the government ${ }^{67}$.

The European Convention provides not merely for the right of legal assistance but for an accused person, "if he has not sufficient means to pay for legal assistance, to be given it free when the interests of justice so require". In contrast the Commonwealth constitutions provide only a right to counsel at the expense of the accused and few of these new states have adequate provisions for legal aid except in capital cases. An accused person is, however, entitled under the bills of rights to the assistance of an interpreter (without payment) if he cannot understand the language of the trial court. Lack of an interpreter at the trial in Kenya of a Portuguese speaking foreigner resulted in his appeal being allowed ${ }^{68}$ and in a Nigerian case the court indicated that in applying the constitutional guarantee it might have regard to the quality of interpreting provided at the trial ${ }^{69}$. The Supreme Court of Nigeria has held, somewhat restrictively, that an accused person who was represented by counsel and who did not at the trial claim the right to an interpreter cannot claim on appeal that he has been deprived of his constitutional right; the matter was determined upon the basis of the old English test as to whether or not there appeared to have been a substantial miscarriage of justice ${ }^{70}$. Does this approach give adequate weight to the bill of rights as new element

61 Gopka v. Inspector-General of Police [1961] 1 All N. L. R. 423.

62 Shemfe v. Commissioner of Police [1962] N. R. N. L. R. 87.

63 Muyimba and others v. Uganda [1969] E. A. 433, although in that case the constitutional right was vindicated by the ordering of a retrial.

64 Ezea v. The Queen [1963] 1 All N. L. R. 245.

65 Yanor and Andiar v. The State [1965] 1 All N. L. R. 193.

66 In re Okafor [1964] 2 All N. L. R. 166, 168

67 Awolowo v. Sarki [1962] L. L. R. 177; [1966] 1 All N. L. R. 178. For a fuller discussion of the right to counsel generally in the context of the bills of rights see James S. Read, “The advantage of counsel", East African Law Journal, Vol. VII, No. 4 (1971), pp. 291-318.

68 Andrea v. Republic [1970] E. A. 46

69 Ajayi and Jos v. Zaria N. A. [1964] N. R. N. L. R. 61.

70 The Queen v. Eguabor [1962] 1 All N. L. R. 287. 
affecting the rules of criminal procedure? In a later case the same court (differently composed with the exception of one judge who delivered the judgment on each appeal) expressly left open the question whether or not, in a case involving a fundamental right, the "saving provision" from the Nigerian legislation can apply ${ }^{71}$ - this specifies that on appeal there should be no alteration of the finding for error, omission or irregularity unless thereby a failure of justice has been occasioned. The significance of this point is that the burden is on the appellant to show a failure of justice - but it should surely be enough for him to show an infringement of a fundamental right, which in itself amounts to a failure of justice.

The bills of rights forbid the application, or increase, of a criminal penalty with retrospective effect. A difficult question might arise where a different penalty is imposed retrospectively, a point which arose but was not clearly decided in a Sierra Leone case: for a motoring offence a driving disqualification was imposed, but this was authorised only by a new Act which had come into force after the date of the offence, the old law permitting imprisonment and/or a fine only. Under the new law, disqualification could be additional to these (clearly an increased penalty) but in the instant case it was the only penalty imposed. The High Court, allowing the appeal on another point, appeared to accept that this might in any event have infringed the Constitution ${ }^{72}$. The rule against retrospective penalty may be applied with regard to a change in the age of the convict. The criminal laws in many Commonwealth states provide that a person under eighteen years of age may not be sentenced to death. The Nigerian Supreme Court has suggested that a person of eighteen or more, convicted of a capital offence committed when he was below that age, might plead the constitution in bar of a death sentence, arguing that he may not receive a sentence "heavier than the penalty in force at the time the offence was committed" 73 .

A major issue was raised in Northern Nigeria regarding the application of the provision that "Every person who is charged with a criminal offence shall be presumed to be innocent until he is proved guilty ..." In Northern Nigeria the criminal procedure, modelled on that of India, requires that, after hearing certain prosecution evidence, the magistrate may, if he is of the opinion "that there is ground for presuming that the accused has committed an offence", frame a charge to which the accused is then asked to plead. In a leading case it was argued that when the accused was thus charged, the presumption of innocence was already gone, in breach of the bill of rights. The Federal Supreme Court decided that the procedure was not incompatible with the Constitution; the magistrate does not in fact presume the accused's guilt when framing the charge but formulates "what seems to him to be the appropriate charge for the offence which prima facie appears to have been committed, and it does not mean that the magistrate has made up his mind that the accused person is guilty" 74 .

Like the European Convention, the Commonwealth constitutions with bills of rights require any civil or criminal case to be given "a fair hearing within a reasonable time by an independent and impartial court established by law". It is, of course, an old established common law maxim that nullum tempus occurrit regi, but this must now yield to the constitutional guarantee. So held Crane, J., in the

\footnotetext{
71 Ajayi and Jos v. Zaria N. A. [1963] 1 All N. L. R. 169.

72 Buckle v. Commissioner of Police 1964-66 A. L. R. S. L. 265.

73 Uwa v. The State [1965] 1 All N. L. R. 356. Capital punishment has been held not to be an *inhuman or degrading punishment": R. v. Runyowa 1966 R. L. R. 42.

74 Ibeziako v. Commissioner of Police [1963] N. R. N. L. R. 88.
} 
High Court of Guyana in finding that a trial in May, 1968, more than three years after the accused had been committed for trial, and with depositions being read in evidence more than three years after they were given, had not been held within a reasonable time as the Constitution required (in the absence of a satisfactory explanation for the delay proved by the prosecution $)^{75}$.

In a number of the cases discussed, however, it appears to be the court's will to adhere to the common law approach rather than to venture upon a new enquiry which might give fuller scope to the bills of rights. One fundamental right protects the individual's privacy against unlawful searches: "Except with his own consent, no person shall be subjected to the search of his person or his property or the entry by others on his premises". In a leading case in Jamaica the appellant had been convicted of possessing dangerous drugs; the whole evidence against him had been found as a result of an unlawful police search. The Judicial Comittee of the Privy Council on final appeal rejected the submission that the evidence should have been excluded by the trial court in its discretion, basing this decision upon a number of authoritative precedents in the courts of England and Scotland which established that if evidence is relevant it is admissible "and the court is not concerned with how the evidence was obtained" (although evidence unfairly, rather than merely unlawfully, obtained may be excluded in the court's discretion). It is only in the penultimate paragraph of a lengthy judgment that reference is made to the appellant's submission that the evidence was obtained in violation of his constitutional right to privacy. The Judicial Committee dealt with this important argument tersely and somewhat opaquely (mentioning but not discussing a comparable Irish case:)

"This constitutional right may or may not be enshrined in a written constitution, but it seems to their lordships that it matters not whether it depends on such enshrinement or simply on the common law as it would do in this country. In either event, the discretion of the court must be exercised and has not been taken away by the declaration of the right in written form"76.

Such a conclusion, appearing almost as an afterthought to a discussion of cases from other jurisdictions and citing no specific authority for its view of a bill of rights, does scant justice to an important constitutional provision which is not found in those jurisdictions. The judgment betrays the attitude of the common lawyer who considers that the common law confers a protection which cannot be surpassed by any constitutional guarantees. In this context the fact that some fundamental rights have parallels in common law rules is clearly a handicap to individuals who seek to show that the constitution has enlarged the protection they enjoy. And if it has not, then why were these bills of rights enacted? American courts have recognised that the only effective sanction against improper searches or other unlawful means of obtaining evidence is to refuse to admit evidence so obtained ${ }^{77}$. How else may the injured individual vindicate his constituional right? Once the court has allowed the illegally obtained evidence to result in a conviction, he is left without an effective remedy and the constitutional guarantee in his case is rendered nugatory.

75 R. v. Ogle 196811 W. I. R. 439.

76 King v. R. [1969] A. C. 304, P. C; [1968] 2 All E. R. 610.

77 Mapp v. Ohio (1961) 367 U. S. 643. "The police will not enforce the rules of lawful search against themselves; the problem arises only when they have already broken those rules". "It has also seemed to many that proceeding to conviction on the basis of evidence unconstitutionally procured made the to many that proceeding to canviction on the basis of evidence unconstitutionally procured made the
courts parties to wrong, putting the judiciary in an untenable moral position". Charles L. Black, Perspectives in Constitutional Law (With revisions, Englewood Cliffs, New Jersey, 1970), pp. 107-8. 


\section{(ii) Judicial interpretation of bills of rights - liberal or literal?}

The courts of England lack experience in applying constitutional texts and common law rules of statutory interpretation are therefore inadequate guides for the judicial construction of bills of rights. Are these constitutional provisions to be interpreted like ordinary Acts of Parliament? The position is anomalous, these constitutions being in fact contained in most cases not even in principal legislation but initially in subsidiary legislation of the United Kingdom, generally as schedules to statutory or prerogative Orders in Council. When they have been re-enacted locally they have sometimes taken the form of ordinary local Acts of Parliament, numbered chronologically with other Acts of the same year (as in Malawi and Kenya). Nevertheless, whatever their form in technical terms, they take effect as fundamental laws, and this is often affirmed by an early provision that "This Constitution is the supreme law". The constitutions are superior to Acts of Parliament, the procedure for enacting which they specify and which are generally declared to be void to the extent to which they may be inconsistent with the constitution.

Yet common law courts may well interpret a constitution by the same methods, principles and presumptions which they would apply to road traffic legislation. The question was argued before the Kenya High Court ${ }^{78}$. On a criminal trial the prosecution sought to give in evidence the answers which the accused had earlier given to an official who administered a mandatory questionnaire authorised by the exchange control laws, which expressly provided that such evidence should be admissible. Defence counsel invoked the constitutional protection: "No person who is tried for a criminal offence shall be compelled to give evidence at his trial". He argued for a liberal interpretation of this provision, to exclude this evidence. Counsel for the state argued for a narrower, literal construction. The court, noting the difference between counsel as to whether or not a constitution should be interpreted differently from an ordinary Act, found support in dicta from other cases for both arguments but approved the view of an Indian judge:

"An argument founded on what is claimed to be the spirit of the Constitution is always attractive for it has a powerful appeal to sentiment and emotion: but a court of law has to gather the spirit of the Constitution from the language of the Constitution. What one may believe or think to be the spirit of the Constitution cannot prevail if the language of the Constitution does not support that view"79.

The Kenya court concluded "that in certain contexts a liberal interpretation may be called for, but in one cardinal respect we are satisfied that a constitution is to be construed in the same way as any other legislative enactment, and that is, where the words used are precise and unambiguous they are to be construed in their ordinary and natural sense". Inevitably this presaged a finding that there was no ambiguity in the constitutional guarantee in question, that it does not refer to statements made by the accused before the trial and put in evidence by prosecution witnesses and that it coincides in fact with the relevant rule in the Evidence Act that and accused can only be called as a witness upon his own appli-

\footnotetext{
78 Republic v. El Mann [1969] E. A. 357. For a discussion of the case see S. A. Adesanya, "The constitutional privilege of an accused to refuse to give evidence: Republic v. El Mann examined", East African Law Journal, Vol. VI, No. 4 (1970), pp. 264-278.

79 per Das, J., in Keshava Menon v. State of Bombay [1951] S. C. R. 228.
} 
cation. The Court noted that in America (under the Fifth Amendment) and in India (art. 20[3] of the Constitution) the protection against self-incrimination is much wider but found that the language of the Kenya provision is quite different:

"Even if some intention were to be assumed from extrinsic considerations, we should, we think, have no more right to assume that the intention of the legislators was to incorporate guarantees as wide as or wider than those found in other constitutions than to assume that, being aware of practical difficulties which may have arisen from guarantees too widely framed, they intended to substitute some guarantee less far-reaching in its effects”.

The most interesting recent case in which the courts have been faced with rival arguments respectively urging a liberal and a literal approach to the constitution of the bill of rights concerned the rights of trade union members ${ }^{80}$, two of whom in Trinidad and Tobago claimed that the Industrial Stabilisation Act 1965 was void as unconstitutional. The Trinidad Constitution, on the shorter model of the Canadian bill of rights, protects "freedom of association and assembly". The Act virtually imposed a system of compulsory arbitration for industrial disputes, making strikes and lockouts illegal (except where the Minister had not referred a reported dispute to the Industrial Court). On final appeal the Judicial Committee of the Privy Council summarised the trade union members' argument for a liberal, and the state's argument for a literal, interpretation: the former was that

"'Freedom of Association' must be construed in such a way that it confers rights of substance and is not merely an empty phrase. So far as trade unions are concerned, the freedom means more than the mere right of individuals to form them: it embraces the right to pursue that object which is the main raison d'être of trade unions, namely collective bargaining on behalf of its members over wages and conditions of employment. Collective bargaining in its turn is ineffective unless backed by the right to strike in the last resort. It is this which gives reality to collective bargaining. Accordingly to take away or curtail the right to strike is in effect to abrogate or abridge that freedom of association which the Constitution confers.

The argument for the state is that 'freedom of association' in . . . the Constitution means no more than it says, that persons are free to associate. It does not mean that the purposes for which they associate, and the objects which in association they pursue, are sacrosanct under the Constitution ..."

The Judicial Committee found that trade unions have other purposes - "social, benevolent, charitable and political" - as well as their main purposes of improving wages and conditions; it quoted the elements of "Freedom of Association" defined in Convention 87 of the International Labour Organisation, which basically reiterates the rights of workers and employers to establish and join organisations free of administrative control or interference. The Judicial Committee found that "All these rights are left untouched by the Industrial Stabilisation Act", which therefore did not leave the assurance of "freedom of association" "empty of worthwhile content". The Act was therefore held to be valid.

A commentator has suggested that a differently constituted court might have come to a different decision in this appeal ${ }^{81}$. It can, however, be argued that the 80 Collymore v. Attorney-General, Trinidad and Tobago [1970] A. C. 538, P. C.; [1969] 2 All E. R. 1207,
P. C.

81 Graham Zellick [1970], Public Law 105-110. 
terse statement of the freedom of association in this Constitution invites a literal approach. What would the result have been if the question had arisen in Jamaica where the Constitution includes the provision commonly found in other Commonwealth states on this point:

"Except with his own consent, no person shall be hindered in the enjoyment of his freedom of peaceful assembly and association, that is to say, his right peacefully to assemble freely and associate with other persons and in particular to form or belong to trade unions or other associations for the protection of his interests."

The term "hindered" was considered in a leading case from Malta, which also indicates that a literal interpretation may be in the interests of the individual. The editor of the Labour Party newspaper impugned the validity of a government circular purporting to prohibit hospital staff taking the paper into hospitals. The Judicial Committee upheld the decision of the lower courts in Malta that the circular had indeed infringed the guarantee of freedom of expression, liberty of circulation being as essential to that freedom as liberty of publication ${ }^{82}$. It was argued for the Minister that the circular did not interfere with the possession and reading of the paper off government premises, but the Judicial Committee pointed out that the Constitution did not refer to the prevention of freedom of expression but to a person being $\mathrm{h}$ in $\mathrm{d}$ e $\mathrm{r}$ e $\mathrm{d}$ in enjoying that freedom. Moreover it rejected an argument which found favour with the original court in Malta, that the hindrance was merely slight, affecting only some 2,660 civil servants; the Court of Appeal had found this to be, considering the size of the population and country; "a relatively considerable number of people" and the Judicial Committee, agreeing, observed trenchantly "The plea that what was done was not very far reaching comes ill from those who reached as far as they could". In an important dictum it was further observed that "where 'fundamental rights and freedoms of the individual' are being considered a Court should be cautious before accepting the view that some particular disregard of them is of minimal account". In this case it was the Minister who sought to resist a too literal interpretation of the Constitution by emphasising the reasonable rights of others, which are mentioned at the opening of the bill of rights; the Judicial Committee considered its decision to be such "as will not allow literalism to run riot but will give common sense its due".

\section{(iii) Exceptions: "Reasonably justifiable in a democratic society"}

The judicial interpretation of the qualifying phrase which allows reasonably justifiable exceptions, within certain categories, to certain fundamental rights, has presented a number of difficult problems of assessment. The Commonwealth contains a wide variety of forms of democratic society and the precise boundaries of democracy are matters for political philosophers rather than lawyers; yet the qualifying phrase most commonly used in the bills of rights permits exceptions unless they are "shown not to be reasonably justifiable in a democratic society". The Trinidad Constitution appears to be a little more specific in tone, recognising

82 Olivier v. Buttigieg [1967] 1 A. C. 115, P. C. quoting the words regarding liberty of circulation from an American case - Ex parte Jackson 96 U. S. 727, 733; 24 L. Ed. 877, 879 - itself cited in an Indian case: Ramesh Thappar v. State of Madras [1950] S. C. R. 594, 597. 
that an Act may expressly derogate from fundamental rights "except insofar as its provisions may be shown not to be reasonably justifiable in a society that has a proper respect for the rights and freedoms of the individual" ${ }^{3}$. In practice this criterion is even more subjective: different judges may disagree widely as to what degree of respect is "proper". In most states the formula appears to put the onus of proving the negative - that the law is not reasonably justifiable - upon the complainant, according with the suggestion that a "presumption of constitutionality" applies in favour of government and legislature ${ }^{84}$. The Constitution of Jamaica employs a simpler phrase - "reasonably required" - and states this as a positive requirement for any derogating provision within the exceptions specified. In all the constitutions there are some guaranteed rights which are not qualified in this broad way but only by limited and specific exceptions: these rights generally include the right to personal liberty, "due process" and a fair trial and the protection of property. However, all the constitutions also include general provisions permitting guaranteed rights to be over-ridden in circumstances of public emergency, and the determination that an emergency exists is a matter for the executive although it normally requires early ratification by the legislative chamber ${ }^{85}$.

Some specific exceptions arise from the nature of "plural societies" which are not uncommon in Commonwealth states, some of which embrace a variety of ethnic divisions. Thus it may be necessary to permit discrimination in the application of personal, customary or religious laws. The Kenya Constitution exempts from the prohibition of discrimination any law regarding "adoption, marriage, divorce, burial, devolution of property on death or other matters of personal law"; the list does not, however, extend to procedural matters such as the machinery for the transmission of property and a discriminatory provision in the law of probate and administration was therefore held unconstitutional ${ }^{86}$. A common exception permits discrimination with regard to persons of a particular description "which, having regard to its nature and to special circumstances pertaining to those persons or to persons of any other such description, is reasonably justifiable in a democratic society". Where legislation in Sierra Leone purported to amend the constitutional definition of citizenship so as to exclude any persons not "of negro African descent", this was held by the Judicial Committee of the Privy Council to be discriminatory and invalid even under the above exception: there was no trace of the special circumstances required for, discrimination by race having been outlawed, "it cannot be that such differences in race would alone constitute 'special circumstances' pertaining to those being treated differently" ${ }^{87}$. However, this was a decision by a majority (reversing the decision of the Court of Appeal to restore the original decision of the Chief Justice) and Lord Guest, dissenting, considered that "Although the Courts are the guardians of the Constitution I

83 Constitution of Trinidad and Tobago, cited in footnote 20 above, s. 5 (1).

84 Y. P. Ghai and J. P. W. B. McAuslan, Public Law and Political Change in Kenya (Nairobi, 1970 Oxford University Press), p. 429; but see below, especially footnotes 91-98. Chapter XI of this work, pp. 407-56, gives a searching analysis of the impact of the bill of rights in Kenya.

85 The precise provisions vary greatly: in Mauritius a proclamation of emergency must be approved within at the most twenty-one days by a resolution supported by at least two-thirds of all members of the Legislative Assembly; in Fiji, such a proclamation is valid for up to six months without Parliamentary approval which itself requires only a simple majority. It is doubtful whether the necessity for such a proclamation can be tested in the courts: see Ningkan v. Government of Malaysia [1968] 1 M. L. J. 119; [1970] A. C. 379, P. C.

86 Re Maangi [19681 E. A. 637.

87 Akar v. Attorney-General, Sierra Leone [1970] A. C. 853, P. C.; [1969] 3 All E. R. 384, P. C.; [1969] J. A. L. 103 ; 1968-69 A. L. R. S. L. 58. For the decisions in the lower courts see: 1967-68 A. L. R. S. L. 283 and 381; [1968] J. A. L. 89, which includes a note on the judgments by J. P. W. B. McAuslan. 
believe that in interpreting the Constitution the ground has to be trod warily and with great circumspection". He had "no hesitation" in holding the amending Act to be "reasonably justifiable in a democratic society": "Any democratic society must in the nature of things have control over the qualifications for citizenship of that society". He would have held that on the face of the amending Act sufficient special circumstances appeared: "These circumstances are the requirement of negro-African descent for citizenship".

Although the prohibition of discrimination protects all "persons", the constitutions include provisions permitting a law to prescribe discriminatorily as against noncitizens; however, administrative action of a discriminatory kind which lacks statutory authorisation in these terms will be unconstitutional. On such grounds the Kenya High Court has held invalid notices to quit served on noncitizen Asian market stall holders ${ }^{88}$ and the refusal of transport licences to a bus company entirely owned by Asians ${ }^{89}$. The economic background to such cases was, of course, the extensive domination of the business life of Kenya by non-citizens but no attempt could be made to argue that the actions impugned were "reasonably justifiable" for that term applies only to laws; in the event, Government policies of Africanisation in the economic field have been furthered by legislation on such matters as trades licensing.

In Zambia the High Court has held it to be reasonably justifiable in a democratic society for customs officers to have the power to seize and open mail under exchange control laws, "on the basis that the customs officer is duly authorised, that his 'reasonable suspicion' is objective and not subjective . .." ${ }^{90}$. This was within the exception to the right of privacy of property and involved no interference with privacy of correspondence because envelopes containing currency notes did not come within the term "correspondence" as interpreted by the judge.

In Zambia also the fundamental rights provisions have precipitated a remarkable echo of the celebrated "flag salute controversy" of a slightly earlier era in the U.S.A. The right to religious freedom was invoked by Jehovah's Witnesses to challenge an educational regulation requiring school pupils to sing the National Anthem and salute the National Flag, upon pain of expulsion for non-compliance. The Chief Justice accepted that this hindered enjoyment of religious freedom but held that the complainant had not discharged the burden of proving that the regulation was not justifiable in a democratic society; he held that there was a presumption of constitutional validity in favour of the legislation. The decision has been criticised as an instance of "judicial self-imposed restraint or judicial passivism" by a commentator who indicated that "since 1938, the U.S. Supreme Court has held that the presumption of constitutional validity of a statute is not applicable where a statute appears prima facie to invade the fundamental rights guaranteed by the First Amendment ... In such a case, the presumption is rather to the contrary ..." ${ }^{91}$. However, two other learned authors state that application of the presumption of constitutionality is predictable and in conformity with the attitude of U.S., Indian and Nigerian courts ${ }^{92}$. The doctrine can certainly be found

88 Madhwa v. City Council of Nairobi [1968] E. A. 406.

89 Devshi \& Co. Ltd. v. Transport Licensing Board [1971] E. A. 289.

90 Chandra P. Gupta, "The Patel currency case", Zambia Law Journal, Vol. 1, No. 1 (1969), pp. $49-56$.

91 Mohammed R. Zafer, "Kachasu's Case", Zambia Law Journal, Vol. 1, No. 1 (1969), pp. 44-48, at p. 48.

92 Y. P. Ghai and J. P. W. B. McAuslan, loc. cit., footnote 84 above. 
in Indian and Nigerian cases ${ }^{93}$, but although it is also an ancient principle in American courts and has been reasserted, for example, "in case after case" under the equal protection clause of the Fourteenth Amendment", "there may be narrower scope for operation of the presumption of constitutionality when legislation appears on its face to be within a specific prohibition of the Constitution"95 (as the regulation in Zambia evidently was) so that "the usual presumption supporting legislation is balanced by the preferred place given in our scheme to the great, the indispensable democratic freedoms secured by the First Amendment. That priority gives these liberties a sanctity and a sanction not permitting dubious intrusions"96. "Where legislative abridgement of the rights is asserted, the courts should be astute to examine the effect of the challenged legislation" ${ }^{97}$. The European Commission of Human Rights has applied "the margin of appreciation" doctrine in determining whether legislation is justifiable "in the public interest"98; in effect, although not of course in theory, it may well be that this doctrine is comparable to the presumption of constitutional validity, for each of these principles exemplifies judicial caution and reluctance on the part of judges (or those charged with the duty of adjudicating) to overrule the decisions of the legislature.

With regard to freedom of speech, the Supreme Court of Nigeria has examined the elements of the offence of sedition, as it is defined in the Criminal Code (in terms which are similar to those found in a large number of Commonwealth states, and which are somewhat wide in extent), and held that the provision is valid, preserving "enough freedom of expression ... in our democratic society" and not preventing fair criticism of the Government ${ }^{99}$. The presumption of constitutionality was applied in a case in the former Northern Region of Nigeria, where a statute had imposed a ban upon any person under sixteen years of age taking part in any political activity. This was a restriction of several of the guaranteed human

93 Ghai and McAuslan cite Chiranjit Lal v. Union of India [1950] S. C. R. 869. They do not support their comment regarding Nigeria with authority but Cheranci v. Cheranci [1960] N. R. N. L. R. 24 affirms the presumption of constitutionality.

94 Baker v. Carr (1962) 369 U.S. 186, 266; 7 L. Ed. 2d. 663, 714. For an old case asserting the general principle see Atchison, Topeka and Santa Fe Railway Co. v. Matthews (1899) 174 U. S. 96, 104 ; 43 L. Ed. 909, 912: "It is a maxim of constitutional law that a legislature is presumed to have acted within constitutional limits . . ."; cited, for example, in Salsburg v. Maryland (1954) 346 U. S. 545, 553; 98 L. Ed. 281, 289.

95 U. S. A. v. Carolene (1938) 82 L. Ed. 1234, 1241. In effect, this judgment gave definition to a newly recognised modification of the general rule and it was presumably the case which Dr. Zafer had in mind in referring to the practice "since 1938" in his note cited at footnote 91 above. It is interresting to recall that the U. S. Supreme Court after that date faced precisely the same issue as the Zambian State Board of Education v. Barnette (1943) 319 U. S. 624, 87 L. Ed. 1628, the "flag-salute" regulation was disallowed, overruling a previous decision in Minersville School District v. Gobitis (1940) 310 U. S. 586, 84 L. Ed. 1375

96 Thomas v. Collins (1945) 323 U. S. 516, 529-30; 89 L. Ed. 430, 440.

97 Schneider v. Irvington (1939) 308, U. S. 147; 84 L. Ed. 155, 165. This case was the basis of a thoughtful note: (1940) 40 Columbia Law Review pp. 531-35 (anon.) which emphasied that the case was important in supporting "the theory that there may be no room for the presumption of constitutionality . . where the statute or ordinance interferes with a civil liberty as distinguished from legislative impairment of an economic privilege :. : (p. 532). The note perceptively contemplates whether "the absence of a presumption of constitutionality may result in the automatic substitution of a presumption of invalidity"; it concluded that "resort might be had to neither of these extremes, but rather to the middle ground" (footnote 13). This indeed has occurred, and the Supreme Court has in recent years given increasing scope to the exception to the presumption of constitutionality: thus, the presumption is not applied "when we are reviewing statutes which deny some residents the right to vote" - Kramer v. Union Free School District (1969) 395 U. S. 621, 23 L. Ed. 2d. 583 at 627-8, 589-90; similarly, racial classifications in legislation are "constitutionally suspect": McLaughlin v. Florida (1964) 379 U. S. 184, 191-2, 13 L. Ed. 2d. 222, 228. Furthermore, now "relative impecuniousness appears to be joining race and national ancestry to compel a complex of traits which, if detectable as a basis of officially sanctioned disadvantage, render such disadvantage "invidious' or 'suspect": Frank I. Michelman, "The sanctioned disadvantage, render such disadvantage 'invidious' or 'suspect"': Frank I. Michelman, "The
Supreme Court, 1968 Term, Foreword", Harvard Law Review Vol. 83 (1969-70), pp. 7-59, at p. 19, pointing out also that there are degrees of "invidiousness" and therefore of "suspectness", which call for "strict review" or "close judicial scrutiny". See Shapiro v. Thompson (1969) 394 U. S. 618, 22 L. Ed. 2d. 600 and Dandridge v. Williams (1970) 397 U. S. 471, 25 L. Ed. 2d. 491.

$98 \mathrm{~A}, \mathrm{~B}, \mathrm{C}$ and D, against the United Kingdom (1967), 23, Collection of Decisions of the European Commission of Human Rights, 66 at p. 73; discussed by D. R. Gilmour, in the article cited above, footnote 5 .

99 D. P. P. v. Obi [1961] 1 All N. L. R. 186. 
rights; was it reasonably justifiable in the interests of public order and morality? The court held that it was reasonably justifiable ("One may well ask at the outset what business juveniles aged fifteen and under have with politics at all ... for juveniles to take part in political activities constitutes a special threat to public order ..."). Account was taken of the fact that men only could qualify to vote, and did so at the age of twenty-one, and that education was still "in its infancy"100. The Nigerian Constitution expressly recognises that the right to freedom of movement may be invaded by restrictions imposed by a reasonably justifiable law in the interest of defence of public order etc. The Supreme Court has somewhat curiously taken the view that a particular order restricting an individual may be examined and such an order was annulled where upon the evidence presented the Court held that it was not reasonably justifiable: "what really matters is the application of laws and regulations to the individual case"101. On the other hand, in another case decided upon the same day and arising out of the same emergency situation, a restriction order served upon another individual was upheld where the evidence revealed "ample grounds for the restriction" ${ }^{102}$. The law under which the orders were made was therefore considered to be reasonably justifiable within the constitutional exception cited, and it is noteworthy that the court was willing to look further, into the application of that law in particular instances, in effect substituting its own discretion for that of the executive authorities.

On the other hand, where the empowering law extends beyond the scope of "reasonably justifiable" provisions it is inconsistent with the relevant constitutional provision and action taken under its authority will be invalid irrespective of the justifiability or otherwise of that action itself. Thus detentions in the associated state of St. Kitts, Nevis and Anguilla during an emergency were held to be unlawful because the relevant emergency laws, which antedated the adoption of the bill of rights, gave the executive authority powers much wider than those which would have been reasonably justifiable; such laws were therefore unconstitutional ${ }^{103}$.

\section{(iv) The right to property}

There have been few reported cases in which the constitutional protection of property rights has been invoked - a surprising fact when the circumstances of new Commonwealth states are recalled, involving often the juxtaposition of reforming nationalist administrations seeking to satisfy the rising expectations of their peoples with the legacy of economic under-development and severe inequalities in the distribution of wealth. Constitutional guarantees regarding property are usually very detailed, suggesting that a special statute might be passed to govern compulsory acquisitions of property in conformity therewith. Where there is no such legislation existing laws will be adapted by interpretation by the courts to conform, as in a Kenya case which went to court merely upon the question of determining the amount of "full compensation" payable to the dispossessed owner ${ }^{104}$. But where a government seeks to take possession of property under a law which does not conform to the constitutional requirements for compulsory

100 Cheranci v. Cheranci [1960] N. R. N. L. R. 24, [1960] J. A. L. 115.

101 Williams v. Majekodunmi [1962] 1 All N. L. R. 324, 328, 413.

102 Adegbenro v. Majekodunmi [1962] 1 All N. L. R. 431.

103 Charles v. Phillips and Sealey 196710 W. I. R. 423; Herbert v. Phillips and Sealey 1967,10 W. I. R. 435. 104 New Munyu Sisal Estates Ltd. v. Attorney-General [1972] E. A. 88. 
acquisition, what are the owner's rights? In a recent appeal from Guyana the Judicial Committee of the Privy Council emphasised that "the landowner's constitutional right was a right not to have her land taken without her consent at all; it was not a right to be paid compensation if the land should be taken without her consent"105.

Land is not the only form of property protected under the bills of rights. In the then dependency of British Guiana in 1964 the Supreme Court, in a decision upheld on appeal, held that a "National Development Savings Levy Ordinance" was ultra vires the Constitution as derogating from the protection against deprivation of property ${ }^{106}$. That protection includes, of course, an exception permitting the levying of taxes, duties etc. The precise definition of a "tax" was considered and the compulsory levy was held to be not a tax but a forced loan. Even if the bonds given could be regarded as compensation, it was not prompt, the authorities had not shown it to be adequate and there was no provision for access to the Supreme Court so that the constitutional protection was infringed in several ways; the statute was therefore invalid.

A number of interesting issues were raised in a recent case concerning the right to property, arising in the context of the successive constitutional changes in Uganda. A court judgment for 67,000 Uganda shillings, being a contract debt owed by the former Government of Buganda, a former "federal state" within Uganda, was given against the Government of Uganda which had taken over the liabilities of the Buganda Government after the removal of the federal states from the constitutional structure. The judgment debt was not paid and when an attempt was made to enforce it the Government relied upon a later Act which provided that no contract with the former Buganda Government was enforceable without ratification by a Minister whose decision was final. The petitioner now alleged that this Act, in depriving him of the benefit of the earlier judgment infringed the constitutional protection against deprivation of property without compensation. Several questions were discussed by the Constitutional Court. Did the constitutional protection of property extend to protect intangible property such as a contract or judgment debt (even, for example, it was argued, a copyright)? If so, was the Act void as purporting to deprive the individual of his property contrary to the bill of rights? The court (by a majority of two to one) answered both questions in the affirmative, indicating that the Act was void and that the individual was entitled to proceed to the enforcement of the earlier judgment. It was argued for the Government that there could have been no "deprivation" of property as there had been no "enrichment" of the Government by the acquisition of property; however, the majority of the court held that the Act purported to enrich the Government in effect by absolving it from paying a debt. The dissenting judge held that the general constitutional protection "from deprivation of property without compensation" " was manifested in effect by the further constitutional provision that no property should "be compulsorily taken possession of" or "compulsorily acquired" except upon certain conditions; a judgment debt, as incorporeal property, could not "be taken possession of" nor could the Government be said to have "acquired" a right of recovery of a debt against itself - the Act was therefore valid and the debt effectively barred, in his view ${ }^{\mathbf{1 0 7}}$.

105 Jaundoo v. Attorney-General, Guyana [1971] A. C. 972, P. C.

106 Lilleyman v. I. R.C. 1964, 13 W. I. R. 224, affirmed 1964, 7 W. I. R. 496.

107 Shah v. Attorney-General (No. 2) [1970] E. A., 523. 
Despite the relatively limited amount of litigation upon this point to date, it is the constitutional protection of property rights which is likely to lead to much litigation in the future in many Commonwealth states as policies of economic development and redistribution of wealth increasingly involve incursions upon established property rights. The present era of extensive government participation in industrial, agricultural and commercial enterprise is likely to be followed by stages of increasing nationalisation and it would be surprising if this did not involve conflicts with existing property-holders. Intricate questions are likely to be raised. Tanzania has in recent years increased state control of the use of land partly by alterations to the fundamental law of land title - successively eliminating the concept of freehold (absolute) title and government leases in order to replace these with the more malleable form of "rights of occupancy". Tanzania has no bill of rights; in a country with such constitutional guarantees, would similar general policies be held to infringe the protection of property rights?

\section{Conclusion}

The Commonwealth experience of bills of rights during the 1960s, measured in terms of the judicial enforcement of these constitutional guarantees, would suggest that such provisions have had only a very limited impact in these new nations. This might, of course, be attributed to a number of factors: the novelty of such guarantees in a common law setting, the early political and economic problems of independence, the cautious reluctance shared by citizens, lawyers and judges alike to demand the amplest application of the constitutional protections. In many of the new Commonwealth states the political pattern at independence involved a powerful national movement with relatively weak opposition parties; the withdrawal of the former opponent, colonial authority, was likely to lead to a near monopoly of political power by a single party, with a dearth of effective balancing institutions. The inclusion of bills of rights in the constitutions may well have been seen at independence as a means of strengthening one national institution, the judiciary, by giving it an additional instrument for intervention in the political liffe of the nation in the jurisdiction to determine conflicts between citizen and state under the bills of rights. Continuity in the personnel of the judiciary, at a time of often rapid "localisation" in most areas of the public service, was one of the significant features of British decolonisation; many expatriate judges of the former colonial judiciary are still serving these new states. The advent of written constitutions with enforceable bills of rights might have wrought a fundamental change in the nature of their role. In practice, however, the paucity of "fundamental rights" cases in most states (always excluding India, the remarkable contrast to other Commonwealth states in many constitutional respects) has meant that the judges have remained aloof from political issues. Many would no doubt say that the alternative - an active, interventionist judicial policy of interpreting the bills of rights in a liberal spirit - would have led swiftly to political confrontation and the weakening of judicial authority.

Of course, it is true that the value of the bills of rights is not to be measured by judicial activity alone. Such constitutional provisions serve an obvious educative function, inculcating in politicians, citizens and public officers an awareness of the acceptable limits of executive power and warning the legal draftsmen and legisla- 
tors of the limits of their power. The bills of rights are intended to contribute substantially to the basic framework of constitutionalism established by these new constitutions. Yet these constitutional guarantees have in fact been less restrictive of executive and legislative power than they might have been; judicial supremacy has not been effectively asserted - partly at least because of the inhibiting effect of common law attitudes. But the political conditions of many of these new states are such that any assertion of judicial supremacy would surely make the nature and role of the judiciary a matter of acute controversy which would ultimately deprive such an assertion of permanent effect ${ }^{108}$.

\section{Abbreviations}

A.C.

A.I.R. S.C.

All E.R.

All N.L.R.

A.L.R. S.L.

D.L.R.

E.A.

J.A..L

L.L.R.

M.L.J.

N.R.N.L.R.

R.L.R.

S.C.R.

S.I.

W.I.R.
Appeal Cases (London).

All India Reporter, Supreme Court (India).

All England Law Reports (London).

All Nigeria Law Reports (Lagos).

African Law Reports - Sierra Leone (New York).

Dominion Law Reports (Canada)

East Africa Law Reports (London).

Journal of African Law (London).

Lagos Law Reports (Lagos).

Malayan Law Journal (Malaysia).

Northern Region of Nigeria Law Reports (Northern

Nigeria).

Rhodesia Law Reports (Rhodesia).

Supreme Court Reports (India).

Statutory Instruments (U.K. - London).

West Indian Law Reports (London).

108 For the role of the judiciary in new states generally see: Claire Palley, "Rethinking the judicial role", Zambia Law Journal, Vol. 1, No. 1 (1969), pp. 1-35; Ghai and McAuslan, op. cit., footnote 84 above;

James S. Read, "Judicial power and the Constitution of Ghana", Review of Ghana Law, Vol. III, No. 2 (1971), pp. 107-28; David La Van Grove, "The 'sentinels' of liberty, The Nigerian judiciary and fundamental rights" [1963] J. A. L. 152-71. 


\title{
Bills of Rights in "The Third World": Some Commonwealth Experiences
}

\author{
By James S. Read
}

The constitutions of the majority of the thirty-two independent states of the Commonwealth include enforceable "bills of rights"; such provisions were adopted, contrary to British constitutional tradition, in almos all of the "new states" of Africa, the Mediterranean, Caribbean and Pacific which became independent of British rule in the 1960s, but the oldest Commonwealth example is found in the lately independent Kingdom of Tonga, where the Constitution dates from 1875. Most of the "bills of rights" are in very similar terms, following the Nigerian model which was itself based upon the European Convention on Human Rights. Some British dependencies, and the autonomous "associated states" of the Caribbean, also have bills of rights. It may, however, be questioned whether the constitutional guarantees of fundamental rights are appropriate or realistic in the "third world" where economic, social and political problems are generally pressing; yet Commonwealth states generally have preserved these forms of protection for individuals despite constitutional changes or upheavals (sometimes even under military government) - perhaps because, with the exception of India, the guarantees, although justiciable, are seldom invoked in the courts. Nevertheless it is difficult to see these provisions as being deeply rooted either in the traditional political structure or in the recent colonial experience of the local communities concerned. Tanzania has rejected this mode of protecting human rights, preferring an active and effective type of "Ombudsman". The Commonwealth pattern of bills of rights, while far-reaching in substantive provisions, includes a number of qualifications and exceptions which limit their applicability. The judicial response, in the small number of reported cases (which are reviewed), has been mainly a cautious one although legislation and executive action has been invalidated in some states, particularly under the prohibition of discrimination. (India, where there is much litigation on the bill of rights, is not included in this study.) Generally the courts have preferred a literal to a liberal interpretation. In the application of a selfimposed "presumption of constitutionality", where legislation is impugned, courts in the Commonwealth appear to be emulating the caution of the European Commission of Human Rights when it invokes the "margin of appreciation" doctrine.

\section{The Kenya Land law reform programme A Model for Modern Africa?}

\section{By Margaret A. Rogers}

The need for reform of their land tenure systems is high on the list of priorities of most independent African countries and is largely due to their inheriting a dual system of land law from the superimposition of a colonial land law system upon their own indigenous law. Kenya has undertaken a radical land law reform programme and as this was first put into operation in the mid-nineteen fifties and reviewed and modified in the late nineteen sixties, it makes an ideal study of how the many problems which are common to most African countries which have 